\title{
Determination of electrolyte composition of saliva and calcium level in blood of children with bronchial asthma
}

\author{
Tamila Y. Shumna, Olexandr V. Voznyi, Yelizaveta S. Lepetchenko \\ Department of Faculty Pediatric, Zaporizhzhia State Medical University, Zaporizhzhia, Ukraine
}

\section{ABSTRACT}

\begin{abstract}
Aim of the study: To analyse the individual biochemical parameters and $\mathrm{pH}$ of saliva and content of calcium in the blood of children with bronchial asthma.

Material and methods: The examination of patients was carried out in the Municipal Non-Commercial Enterprise City Children's Hospital no. 5 in Zaporizhia City Council and the University Clinic of Zaporizhzhia State Medical University. The main study group comprised 49 children aged 5 to 17 years with bronchial asthma, who were taking inhalation glucocorticosteroids for basic control treatment. The comparison group consisted of 29 children without burdened allergic anamnesis. The results were processed in Microsoft Excel for Windows 4.0 and Statistica 6.0.

Results: The level of total calcium in the blood of the children of the main group was equal to 2.33 (2.24; $2.39)$, while in the children of the comparison group it was equal to $2.51(2.42 ; 2.55)$ at $p<0.001$. This was also characterised by a decrease in the amount of ionised calcium determined in saliva: $0.55(0.45 ; 0.69)$ in the main group versus $0.86(0.75 ; 0.94)$ in the comparison group, at $p<0.001$. When determining the saliva $\mathrm{pH}$, the data obtained indicated a shift of indicators toward an increase in acidity in the main group: 6.90 (6.88; $7.10)$ with stable indicators $7.13(6.87 ; 7.32)$ in the control group at $p=0.015$. A slight difference between the obtained data was also found when comparing the chlorine ion content in saliva: $28.6(25.9 ; 32.0)$ in the main group versus $32.2(28.1 ; 34.7)$ in the control group, at $p=0.048$. The inverse relationship between the levels of potassium ions and saliva $\mathrm{pH}$ was detected $(-0.31$ in the main group and -0.37 in the comparison group). Conclusions: Our study confirms the presence of changes in the electrolyte composition of saliva and the content of calcium in the blood of children with bronchial asthma on the background of taking inhalation glucocorticosteroids.
\end{abstract}

\section{KEY WORDS:}

children, calcium, bronchial asthma, electrolytes.

\section{INTRODUCTION}

Bronchial asthma is a leader among other chronic respiratory diseases in terms of prevalence, duration, number of complications, and severity of treatment. However, the concept of bronchial asthma therapy has changed recently: its goal was not to alleviate symptoms, but to control the disease and to improve the quality of patients' life $[1,2]$.

According to clinical recommendations, the main way of administration of basic therapy for bronchial asthma is inhalation. This enables the delivery of medicinal substances directly to the respiratory tract and causes a high therapeutic effect on the underlying disease [3].

\section{ADDRESS FOR CORRESPONDENCE:}

Tamila Y. Shumna, Department of Faculty Paediatric, Zaporizhzhia State Medical University, 26 Mayakovsky Ave, 69000 Zaporizhzhia, Ukraine, ORCID: 0000-0003-0557-6714, e-mail: tshumnaya72@gmail.com 
However, the effect of these medications on oral homeostasis has not been sufficiently studied. According to the literature data, the use of inhaled glucocorticosteroids causes changes in the physico-chemical and immunological parameters of the oral fluid (decrease in salivation rate, decrease in calcium, phosphorus, lysozyme content, and viscosity). In addition, inhaled corticosteroids cause a decrease in the $\mathrm{pH}$ of saliva and dental plaque because the $\mathrm{pH}$ of most of them is less than 5.5. These changes, combined with a decrease in salivation rate, decreased secretory IgA amount, and amylase in saliva, make children with bronchial asthma more vulnerable to caries and contribute to the development of a cariesogenic situation in the oral cavity [4-7]. In addition, a number of researchers state that the use of inhaled glucocorticosteroids causes impaired bone formation, decreased mineral density, and growth retardation [8]. It can also be argued that glucocorticosteroids have the ability to influence the various mechanisms of calcium homeostasis. When studying the functional state of the calcium-regulating system in patients with different forms of bronchial asthma, it was found that no group had a normalisation of calcium re-absorption curves. However, there was an acute impaired secretion of calcitonin and parathormone in the group receiving steroid therapy $[9,10]$. The changes detected can be both primary (associated with the underlying disease) and secondary (caused by the effect of therapy) [11].

However, the literature data on the effects of inhaled glucocorticosteroids on calcium metabolism remain controversial [12].

The aim of this work was to study the individual biochemical parameters and $\mathrm{pH}$ of saliva and content of calcium in the blood of children aged 5-17 years with bronchial asthma.

\section{MATERIAL AND METHODS}

The clinical study was conducted on the basis of the Allergic Department of the Municipal Non-Commercial Enterprise City Children's Hospital no. 5 of Zaporizhia City Council and the Department of Therapeutic, Orthopaedic, and Paediatric Dentistry of the University Clinic of Zaporizhia State Medical University. By randomisation, the main study group (group I) comprising 49 children aged 5 to 17 years was established among children with bronchial asthma, who were taking only inhalation glucocorticosteroids for basic control treatment of the underlying disease. Other concomitant medications were not used. In hospital, this group of children used a nebuliser to deliver a suspension-glucocorticosteroid for inhalation (Budesonide) with a recommended maintenance dose of $0.5 \mathrm{mg}$ per day for 10 days. The comparison group (group II) comprised 29 children without burdened allergic anamnesis. Blood and saliva w ere sampled from all children using standard techniques. Passive drool was used for the collection of saliva. We used this method early in the morning (8-10 a.m.). Children were asked to refrain from eating, drinking, or oral hygiene procedures for at least one hour prior to the collection. They were also asked not to use any glucocorticosteroids on those mornings. The time elapsing between last inhaler use and saliva sampling was at least 12 hours. Participants were asked to drool saliva into a vial. They were given distilled drinking water, asked to rinse their mouth out well for $1 \mathrm{~min}$, and expectorate the water before the procedure. Five minutes after this oral rinse, children spat into a $10 \mathrm{ml}$ sterile tube. Approximately $5 \mathrm{ml}$ of saliva was collected. The biochemical indices of the saliva were determined in the supernatant mixed saliva fraction obtained by its centrifugation at $3000 \mathrm{rpm}$ within $10 \mathrm{~min}$ [13]. In the biochemical study of blood, the content of total calcium in the serum was quantitatively determined by colour reaction [14]. This study was accepted by the Zaporizhzhia State Medical University Bioethics Commission. According to the principles of bioethics, the parents of all children gave informed consent to their examination. The results were processed in Microsoft Excel for Windows 4.0 and Statistica 6.0. The data obtained were verified for normality by Shapiro-Wilk test. As far as the distribution differed from normal $(p<0.05)$, the data are presented as median and inter-quartile ranges Me (Q25; Q75).

\section{RESULTS}

The study showed that in the main group the homeostasis of calcium was disturbed in the direction of reducing its amount, and it did not depend on the received therapy and control methods. Thus, the level of total calcium in the blood of the children of the main group was equal to $2.33(2.24 ; 2.39)$, while in the children of the comparison group it was equal to $2.51(2.42 ; 2.55)$, at $p<0.001$. This was also characterised by a decrease in the amount of ionised calcium determined in saliva: 0.55 $(0.45 ; 0.69)$ in the main group versus $0.86(0.75 ; 0.94)$ in the comparison group, at $p<0.001$, which showed a significant statistical difference in both cases. When determining the saliva $\mathrm{pH}$, the data obtained indicated a shift of indicators toward an increase in acidity in the main group: $6.90(6.88 ; 7.10)$ with stable indicators 7.13 (6.87; 7.32 ) in the control group, at $p=0.015$. A slight difference between the obtained data was also found when comparing the chlorine ion content in saliva: 28.6 (25.9; 32.0) in the main group versus $32.2(28.1 ; 34.7)$ in the control group, at $p=0.048$. However, in determining the quantitative content of sodium and potassium, no significant difference was found, although the indicators were somewhat lower in the main group: $12.5(9.57 ; 16.4)$ versus $12.7(10.7 ; 13.3)$ and $18.1(15.5 ; 23.7)$ versus 20.9 (17.6; 23.7), respectively, at $p>0.05$. The data obtained are shown in Table 1 for the main (1) and control (2) groups.

For a better understanding of the results, Spearman's rank-order correlation analysis was performed, which 
TABLE 1. Calcium levels in blood and electrolyte compositions of saliva

\begin{tabular}{|l|c|c|c|c|c|}
\hline Indicators & Median 1 & $\begin{array}{c}\text { Inter-quartile range 1 } \\
\text { Q25; Q75 }\end{array}$ & Median 2 & $\begin{array}{c}\text { Interquartile range 2 } \\
\text { Q25; Q75 }\end{array}$ & $p$ \\
\hline Total calcium & 2.33 & $2.24 ; 2.39$ & 2.51 & $2.42 ; 2.55$ & $<0.001$ \\
\hline Sodium & 12.5 & $9.57 ; 16.4$ & 12.7 & $10.7 ; 13.3$ & $>0.05$ \\
\hline Potassium & 18.1 & $15.5 ; 23.7$ & 20.9 & $17.6 ; 23.7$ & $>0.05$ \\
\hline Chlorine & 28.6 & $25.9 ; 32.0$ & 32.2 & $28.1 ; 34.7$ & 0.048 \\
\hline Ionized calcium & 0.55 & $0.45 ; 0.69$ & 0.86 & $0.75 ; 0.94$ & $<0.001$ \\
\hline Saliva pH & 6.9 & $6.88 ; 7.1$ & 7.13 & $6.87 ; 7.32$ & 0.015 \\
\hline
\end{tabular}

TABLE 2. Correlation analysis between calcium levels in blood and electrolyte compositions of saliva

\begin{tabular}{|c|c|c|c|c|c|c|c|c|c|c|c|c|}
\hline \multirow[t]{2}{*}{ Indicators } & \multicolumn{2}{|c|}{ Total calcium } & \multicolumn{2}{|c|}{ Sodium } & \multicolumn{2}{|c|}{ Potassium } & \multicolumn{2}{|c|}{ Chlorine } & \multicolumn{2}{|c|}{ Ionised calcium } & \multicolumn{2}{|c|}{ Saliva pH } \\
\hline & I & II & I & II & $I$ & II & I & II & I & II & I & II \\
\hline Total calcium & 1.00 & 1.00 & 0.20 & 0.13 & 0.13 & -0.32 & $0.35^{*}$ & -0.43 & 0.19 & 0.23 & -0.10 & 0.15 \\
\hline Sodium & 0.20 & 0.12 & 1.00 & 1.00 & -0.23 & -0.04 & $0.30^{*}$ & $0.39^{*}$ & $0.37^{*}$ & $0.42^{*}$ & -0.11 & 0.04 \\
\hline Potassium & 0.13 & -0.32 & -0.23 & -0.04 & 1.00 & 1.00 & $0.30^{*}$ & 0.23 & -0.19 & 0.10 & $-0.31^{*}$ & $-0.37^{*}$ \\
\hline Chlorine & $0.35^{*}$ & $-0.43^{*}$ & $0.30^{*}$ & $0.39^{*}$ & $0.30^{*}$ & 0.23 & 1.00 & 1.00 & $0.30^{*}$ & 0.21 & -0.17 & -0.14 \\
\hline Ionised calcium & 0.19 & 0.23 & $0.37^{*}$ & $0.42^{*}$ & -0.19 & 0.10 & $0.30^{*}$ & 0.21 & 1.00 & 1.00 & 0.08 & -0.08 \\
\hline Saliva pH & -0.10 & 0.15 & -0.11 & 0.15 & $-0.31^{*}$ & $-0.37^{*}$ & -0.17 & -0.14 & 0.08 & -0.08 & 1.00 & 1.00 \\
\hline
\end{tabular}

"statistically significant results $p<0.05$, I - children with bronchial asthma, II - children without burdened allergic anamnesis

showed the dependencies between the results obtained. Thus, the inverse relationship between the levels of potassium ions and saliva $\mathrm{pH}$ was detected.

The Spearman's correlation coefficient was equal to -0.31 in the main group and -0.37 in the comparison group. The data obtained indicated a correlation dependence of the mean strength, which is characteristic for both the main and control groups $(p=0.78)$. The results obtained are shown in Table 2.

\section{DISCUSSION}

Having analysed the current medical literature, we found that this problem was understudied. In addition, the existing data are quite contradictory. The effect of inhaled glucocorticosteroids on electrolyte homeostasis is consistent, but the results of various scientists differ in their indicators. Thus, Ruzanova and Timchyshyn state that disorders of calcium metabolism in children with bronchial asthma are manifested as an increase in the amount of total and ionised calcium in the serum [15].

Nevertheless, having analysed the data of 120 children, Poleshchuk et al. obtained results that showed a decrease in the amount of both total and ionised calcium, including in saliva [16]. A number of scientists also studied the acidity of saliva, indicators of which were lower in all experiments. This result is directly related to the use of basic therapy medications having lower acidity [17].

However, none of the scientists analysed the electrolyte composition of saliva in more detail and did not find any dependence between cations and saliva anions and their effect on acidity.

\section{CONCLUSIONS}

Our study confirms the presence of changes in the electrolyte composition of saliva and the content of calcium in blood of children with bronchial asthma on the background of taking inhalation glucocorticosteroids. This allows us to assume that the changes are caused by both the underlying disease and the use of basic therapy. This leads us to a deeper study of the stated problem and to an introduction of methods of regulation and normalisation of the above indicators.

In the future, we are planning to study the composition of microflora in plaque and to conduct densitometry in children with bronchial asthma.

\section{ACKNOWLEDGMENTS}

The performed study is a fragment of the scientific and research work of the Department of Faculty Paediat- 
rics on the topic: "Optimisation of differential diagnostics and treatment of allergic and other diseases in children of different ages" (state registration no. 0118U004254).

\section{DISCLOSURE}

The authors declare no conflict of interest.

\section{REFERENCES}

1. Global Initiative for Asthma (GINA). [Global Initiative for Asthma - GINA]. Astma ta Alerhiia 2017; 3: 72-83 [in Ukrainian]

2. Global Initiative for Asthma (GINA). Kyshen'kove kerivnytstvo z likuvannya i profilaktyky bronkhial'noyi astmy (u doroslykh i ditey starshe 5 rokiv) [Pocket guide for the treatment and prevention of bronchial asthma (in adults and children over 5 years old) Global Initiative for Asthma - GINA]. Astma ta Alerhiia 2017; 2: 43-56 [in Ukrainian].

3. Tsoy AN. Faktory' effektivnosti ingalyacionnoj terapii I vy'bor poroshkovogo ingalyatora [Factors for the effectiveness of inhalation therapy and the choice of a powder in haler]. Atmosfera. Pul'monologiya i Allergologiya 2009; 3: 16 [in Russian].

4. Anjomshoaa I, Cooper ME, Vieira AR. Caries is Associated with Asthma and Epilepsy. Eur J Dent 2009; 3: 297-303.

5. Stenson M, Wendt LK, Koch LK, et al. Oral health in preschool children with asthma. Int J Paediatr Dent 2008; 18: 243-250.

6. Tanaca K, Miyake Y, Arakawa M, et al. Dental caries and allergic disorders in Japanese children: the Ryukyus Child Health Study. J Asthma 2008; 45: 795-799.

7. Mazzoleni S, Stellini E, Cavalery E, et al. Dental caries in children with asthma undergoing treatment with short acting beta2-agonist. Eur J Paediatr Dent 2008; 9: 132-138.

8. Tattersfield AE, Town GL, Johnell O, et al. Bone mineral density in subjects with mild asthma randomized to treatment with inhaled corticosteroids or non-corticosteroid treatment for two years. Tho$\operatorname{rax} 2010: 56: 272-278$.

9. Chuchalin AG, Berova MM. Funktsional'noye sostoyaniye kal'tsiyreguliruyushchey sistemy u bol'nykh bronkhial'noy astmoy [The functional state of the calcium-regulating system in patients with bronchial asthma]. Klin Med 1989; 8: 56-59 [in Russian].

10. Khramtsova SN, Shcheplyagina LA. Rol' czitokinov i gormonov v formirovanii kostnoj tkani (Soobshenie 1) [The role of cytokines and hormones in the formation of bone tissue (Message 1)]. Rossiyskiy Pediatricheskiy Zhurnal 2005; 5: 25-29 [in Russian].

11. Rubin J, Biskobing DM, Jadhav L, et al. Dexamethasone promotes expression of membrane-bound macrophage colony-stimulating factor in murine osteoblast-like cells. Endocrinology 1998; 139: 1006-1012.

12. Goldstein MF, Fallon JJ, Harning R. Chronic glucocorticoid therapy-induced osteoporosis in patients with obstructive lung disease. Chest 1999; 116: 1733-1749.

13. Nazarenko GI, Kishkun AA. Klinicheskaya otsenka rezul'tatov laboratornykh issledovaniy: uch. Posob [Clinical evaluation of laboratory research results: study. Manual]. Meditsina 2000; 544 [in Russian].

14. Gorinova YUV. Kostnaya mineral'naya plotnost' u detey s khronicheskimi zabolevaniyami legkikh [Bone mineral density in children with chronic lung diseases]. Voprosy Sovremennoy Pediatrii. 2004; 3: 95.

15. Ruzanova EV, Timchyshyn OL. Osobennosti kal'tsiy-fosfornogo metabolizma u detey s bronkhial'noy astmoy [Features of calciumphosphorus metabolism in children with bronchial asthma]. Aktual'ni problemy suchasnoyi medytsyny 2007; 7: 137-139 [in Russian].
16. Poleshchuk OYU, Romanenko IG, Kaladze KN. Uroven' kontsentratsii ionizirovannogo kal'tsiya $\mathrm{v}$ rotovoy zhidkosti u detey $\mathrm{s}$ generalizovannym khronicheskim kataral'nym gingivitom na fone bronkhial'noy astmy [The level of concentration of ionized calcium in the oral fluid in children with generalized chronic catarrhal gingivitis on the background of bronchial asthma]. Vesnik Meditsinskogo Instituta «REAVIZ» 2017; 4: 48-52 [in Russian].

17. Vydoynyk OYA. Pokaznyky homeostazu rotovoyi porozhnyny u ditey zi stomatolohichnoyu zakhvoryuvanistyu na foni bronkhial'noyi astmy [Indicators of oral homeostasis in children with dental morbidity against a background of bronchial asthma]. Visnyk Problem Biolohiyi i Medytsyny 2014; 110: $47-49$ [in Ukrainian]. 